\title{
高温超電導材料の電磁気的・機械的特性の評価
}

\author{
長村 光造 ${ }^{* 1, \dagger}$, 和田 仁 $^{{ }^{*} 2}$, 落合 庄治郎 ${ }^{* 3}$, 北條 正樹 ${ }^{* 4}$, 松下 照男 ${ }^{* 5}$, 秋田 調 ${ }^{* 6}$, \\ 菅野 未知央 ${ }^{* 7}$, 町屋 修太郎 ${ }^{* 8}$, David LARBALESTIER ${ }^{* 9}$, Arman NYILAS ${ }^{* 10}$, \\ Werner PRUSSEIT ${ }^{* 11}$, Alex OTTO ${ }^{* 12}$, Damian HAMPSHIRE ${ }^{* 13}$
}

\section{Progress of Evaluation Techniques for Electromagnetic and Mechanical Properties of High Temperature Composite Superconductors}

\author{
Kozo OSAMURA $^{* 1, \uparrow}$, Hitoshi WADA ${ }^{* 2}$, Shojiro OCHIAI ${ }^{* 3}$, Masaki HOJO ${ }^{* 4}$, Teruo MATSUSHITA ${ }^{* 5}$, \\ Shirabe AKITA ${ }^{* 6}$, Michinaka SUGANO ${ }^{* 7}$, Shutaro MACHIYA ${ }^{* 8}$, David LARBALESTIER ${ }^{* 9}$, \\ Arman NYILAS ${ }^{* 10}$, Werner PRUSSEIT ${ }^{* 11}$, Alex OTTO ${ }^{* 12}$ and Damian HAMPSHIRE ${ }^{* 13}$
}

Synopsis: Remarkable progresses in the development of high temperature superconductors (HTS) such as BSCCO-2223 tapes and YBCO coated conductors have been achieved in recent years, where very high engineering critical current densities $\left(J_{\mathrm{e}}\right)$ were reached in long conductor length. It is however necessary to realize simultaneously high strain tolerance of $J_{\mathrm{e}}$, low AC losses and high mechanical strength in order to apply them for practical uses. In the first part of the present review, some critical techniques to improve microstructures for achieving total performance of BSSCO tapes as well as YBCO coated conductors are suggested. In the major part, the recent progress of evaluation techniques of mecahno-electromagnetic properties is introduced. The HTS's are typical composite material consisting of essentially five components. Here the analytical technique is proposed to make clear the mechanical properties based on the rule of mixture, while the quantitative experimental method to measure tensile properties is introduced. The critical current is very sensitive on strain. The strain dependency could be divided into two regions. In the reversible region, the critical current decreases monotonously for BSCCO tapes. On the other hand, YBCO coated conductors give a so-called Ekin's intrinsic behavior for the change of critical current, where a maximum of critical current appears during the process of increasing tensile strain. In order to understand fully the strain dependences of critical current, it is absolutely necessary to elucidate the strain state exerted on the superconducting component in the composite. Recently the direct measurements of local strain have been succeeded by means of diffraction techniques using neutron and synchrotron radiation. Their interesting results including a new science are reported in the present review.

Keywords: BSCCO-2223 tapes, YBCO coated conductors, reversible strain limit, neutron diffraction, synchrotron radiation

Received February 25, 2009

${ }^{*} 1$ 財団法人 応用科学研究所

干 606-8202＼cjkstart京都市左京区田中大堰町 49 番地

Research Institute for Applied Sciences, Tanaka Ohi-cho 49, Sakyo-ku, Kyoto 606-8202, Japan

${ }^{* 2}$ 東京大学 大学院新領域創成科学研究科 物質系専攻 干 277-8561 千葉県柏市柏の葉 5-1-5

Graduate School of Frontier Sciences, The University of Tokyo, Kashiwa 277-8561, Japan

*3 京都大学 大学院工学研究科 材料工学専攻

于 606-8501 京都市左京区吉田本町

Graduate School of Engineerinng, Kyoto University, Yoshida, Sakyo-ku, Kyoto 606-8501, Japan

${ }^{* 4}$ 京都大学 大学院工学研究科 機械理工学専攻

于 606-8502 京都市左京区吉田本町

Graduate School of Engineering,Kyoto University, Sakyo-ku, Yoshida, Kyoto 606-8501, Japan

*5 九州工業大学 大学院情報工学研究院 電子情報工学研究系 干 820-8502 福岡県飯塚市川津 680-4

Department of Computer Science and Electronics, Kyushu Institute of Technology, 680-4 Kawazu, Iizuka 820-8502, Japan

*6 財団法人 電力中央研究所 企画グループ
干 100-8126 東京都千代田区大手町 1-6-1

Central Research Institute of Electric Power Industry, 1-6-1 Otemachi, Chiyoda-ku, Tokyo 100-8126, Japan

*7 京都大学 大学院工学研究科 電子工学専攻 于 615-8510 京都市西京区京都大学桂

Department of Electronic Science and Engineering, Kyoto University, Katsura, Kyoto 820-8502, Japan

*8 大同工業大学 工学部 機械工学科 ₹ 457-8530 名古屋市南区滝春町 10 番地 3

Department of Mechanical Engineering, Daido Institute of Technology, Takiharu, Minami-ku, Nagoya 457-8530, Japan

*9 Applied Superconductivity Center, National High Magnetic Field Laboratory, Tallahassee, FL 32311 USA

${ }^{*} 10$ Cryogenic Engineering \& Materials Expertise, CEME, Margeritenweg 1, Stutensee D76297 Germany

*11 THEVA Duennschichnik GmbH, Rote-Kreuz-Strasse 8,85737 Ismaning, Germany

*12 American Superconductors Company Ltd., Westborough, MA 01581, USA

*13 Physics Department, University of Durham, Durham, DH1 3LE, UK

† E-mail: kozo_osamura@rias.or.jp 


\section{1. はじめに}

地球温暖化問題，エネルギー源の確保や有効利用といっ たエネルギーセキュリテイー問題も今や待ったなしの差し 迫つた社会問題となりつつあり, 超電導技術がより積極的 にその役割を果たすことが期待されている ${ }^{1)}$ 。最近になり, 高温超電導材料の製造技術の著しい進歩により，ほぼ実用 化に近い高性能な線材が市販されるようになってきた。実 際の個別の応用には, それぞれ特有の仕様も要求されるが, 一般的には 3 大機能, すなわち高い工学的臨界電流密度, 高強度・高勒性，低い交流損失がバランスした線材という ことができよう 2)。さらに何といっても，均質な長尺の線 材の供給は機器設計において, コストのかからない理想的 な超電導機器の実現に重要な要素となる。

現在数種の高温超電導物質が実用化に向けて線材として の研究開発が行われている。機能の高性能化に伴い, その 評価方法も対応して高度化することが望まれる。まさに材 料開発と評価は車の両輪ということができる。ここでは, 代表的な高温超電導線材について, 新しい特性の評価方法, とくに機械・電磁気特性の評価について報告することにし た。同一の評価方法・基準で異なる線材の特性を相互比較 することは, 特色ある各種線材を適材適所で利用していく ために有用な情報になると考えられる。

\section{2. 微細組織と臨界電流}

現在開発されている, 代表的な高温超電導線材の工学的 臨界電流密度 $\left(J_{\mathrm{e}}\right)$, つまり臨界電流 $I_{\mathrm{c}}$ を線材断面積で割つ た值を Table 1 に示す。いずれも $100 \mathrm{~A} / \mathrm{mm}^{2}$ 以上の值を持 ち, 工学的利用可能なレベルにまで達しているが, 今後は 各線材はそれぞれにさらに高い $J_{\mathrm{e}}$ を実現できる潜在的な 高いポテンシャルをもつので, 他の機能とバランスのとれ た材料開発が望まれている。

現状の BSCCO-2223 線材では $J_{\mathrm{e}}$ は粒界弱結合によって 支配されており，特定されたピンサイトは知られていな い。DI-BSCCO では加圧により, 結晶成長上, 不可避的に

Table 1 Engineering critical current density of practical superconducting wire at $77 \mathrm{~K}$

\begin{tabular}{|c|l|c|c|}
\hline $\begin{array}{c}\text { SC } \\
\text { materials }\end{array}$ & $\begin{array}{c}\text { Manufacturer } \\
\text { and structural feature }\end{array}$ & $\begin{array}{c}I_{\mathrm{c}} \\
(\mathrm{A})\end{array}$ & $\begin{array}{c}J_{\mathrm{e}} \\
\left(\mathrm{A} / \mathrm{mm}^{2}\right)\end{array}$ \\
\hline \multirow{4}{*}{ Bi2223 } & SEI Insert & 180 & 192 \\
\cline { 2 - 4 } & SEI SUS3Ply & 180 & 145 \\
\cline { 2 - 4 } & EHTS & 122 & 158 \\
\cline { 2 - 4 } & AMSC SUS3ply & 155 & 172 \\
\hline \multirow{3}{*}{ YBCO } & SuperPower SCS & 247 & 214 \\
\cline { 2 - 4 } & AMSC 344S & 120 & 181 \\
\cline { 2 - 4 } & EHTS & 137 & 274 \\
\hline
\end{tabular}

生ずるボイドを消滅させることができるので, 非超電導相 の量が最小化されている, その結果 Table 1 に示すように 180 A クラスの長尺線材の製造が可能になってきている。 今後は 2212 相や他の非超電導相の量をさらに減少させ, Bi2223 板状微結晶の $\mathrm{c}$ 軸配向さらに面内配向へと高配向 化させることが課題であると考えられる。

その配向性の評価方法の一つとして中性子回折法が注目 されている ${ }^{3)}$ 。中性子は物質透過能が高いので BSCCO テー プ材を非破壊で評価することができるからである。Fig. 1 はテープの長手方向に垂直にどれだけ（220）面が向いて いるかを示している。つまりテープ面に対する $\mathrm{c}$ 軸配向の 度合を示すもので, Off-set angle で c 軸がテープ法線に平 行で, 角度が大きくなるに従い, c 軸がどれだけテープ面 から傾いたかを示すと解釈できる。半価幅は約 18 度であり， 臨界電流の角度依存性から評価した配向角の傾向と一致す

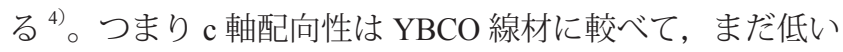
レベルにあり, 一層の結晶成長技術の向上が望まれる。こ のように中性子回折法の有用性が明らかになったが, いず れは極点図を測定しより定量的な評価が可能となる。

YBCO 線材では結晶成長技術の著しい進展により面内 の 2 軸配向性が向上してきており, IBAD では結晶粒界の 影響はほぼ無くなりつつあり, RABiTS 系では低磁場領 域で結晶粒界による弱結合の影響が残されている。ASCNHMFL での LTLSM による観察結果によれば ${ }^{5)}$, 板状 YBCO 相のほとんどは c 面が面内配向するが，まれに 90 度回転した $\mathrm{a}$ 軸粒が形成される, $\mathrm{a}$ 軸粒の周りで電流が迂 回し, 電流が集中する様子が Fig. 2 に示すように観察され ている。 $\mathrm{BaZrO}_{3}$ 相に代表される微細析出物の分散がピン サイとして有効であることが報告される一方, 高臨界電流 膜は組織的に YBCO一層の均質なものではなく, 非超電

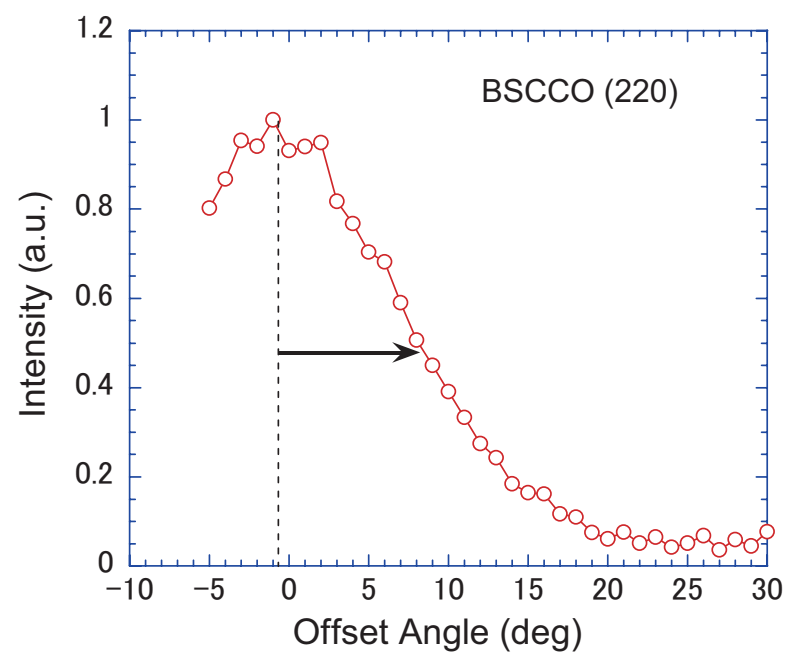

Fig. 1 Change of neutron diffraction intensity from BSCCO (220) plane as a function of offset angle, where the angle zero corresponded to the (220) plane perpendicular to the axis longitudinal to the tape and the scattering vector was inclined from this normal axis. 


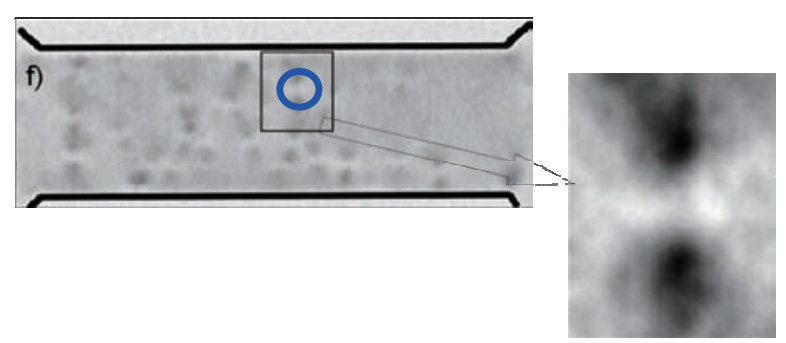

Fig. 2 LTLSM image showing the detour and concentration of super current around non-SC inclusions in the YBCO thin film placed in the magnetic field of 5 tesla.

導相との混相状態であることが明らかにされている。この ような組織を持つ長尺のテープでは, まだ電流密度に大き な変動がみられる等，結晶成長条件が制御しきれていない ので，LTLSM，SQUID， Hall probe 等の微視的かつ局所的 な観察手段により原因を詳細に調べることがさらに必要に なると考えられる。

将来の磁束ピンニング特性の向上を目的として YBCO 線材に人工ピンを導入する傾向にあるが，そうした場合の ピンニング特性を理解しておくために，DyBCO 線材に重 イオン照射を行い，それによって生じた円柱状欠陥のピン ニング特性が調べられた ${ }^{6}$ 。Fig. 3 は基板に垂直な方向に 金イオンを照射した試料について SQUID 磁力計で測定し た磁化から見積もった臨界電流密度の増加の様子で，金イ オンによる円柱状欠陥の半径は約 $5 \mathrm{~nm}$ ，マッチング磁界 は $1 \mathrm{~T}$ である。1 $\mathrm{T}$ 程度の磁界において臨界電流密度が大 きくなり,磁束とピンのマッチング効果の傾向が見てとれ, また，臨界電流密度の増加は高温において顕著となる。こ

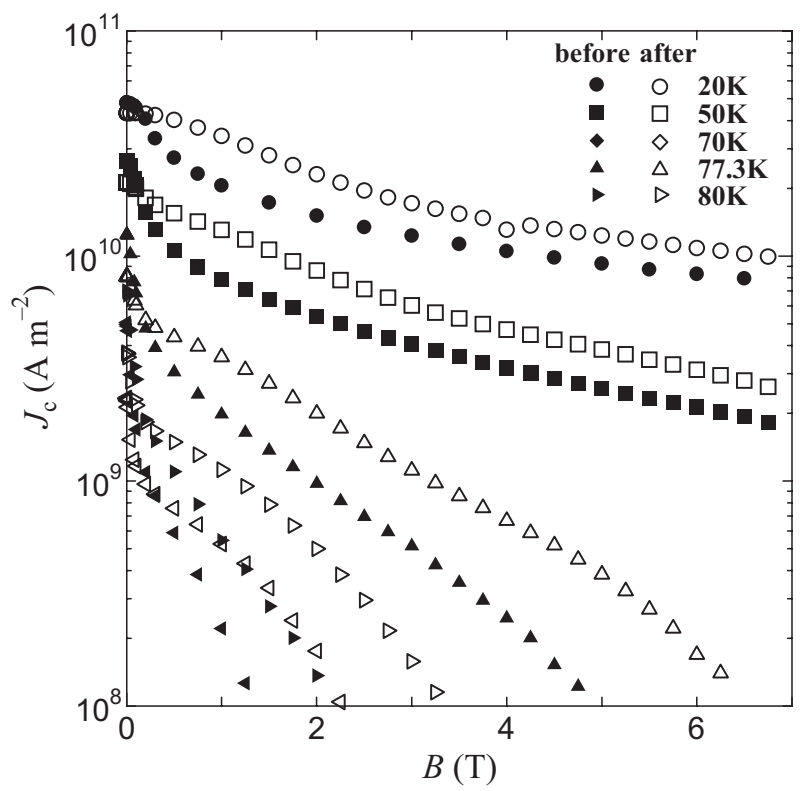

Fig. 3 Change of critical current density as a function of magnetic field for DyBCO coated conductor radiated $\mathrm{Au}$ ions, where open and solid symbols indicate the data before and after irradiation.
れによって, 不可逆磁界もまた大きく改善されている。こ うしたピンニングを磁束クリープ・フローモデルを用いて 解析してみると，実験結果を説明するにあたって仮定した ピンニングの強さは, ほぼ半径が $5 \mathrm{~nm}$ の常伝導円柱によっ て得られるものに等しく, 理論的計算が妥当であったこと が示される。したがって, 円柱状照射欠陥については現状 のピンニング理論で解析が可能であることから,ナノ・ロッ ドのような人工ピンについても解析できると期待される。

\section{3. 低電界領域での輸送特性}

従来から超電導から常伝導への転移を調べるため, 試料 に電流を流し，電流増加による電圧の発生を

$$
V=V_{c}\left(\frac{I}{I_{c}}\right)^{n}
$$

のように定式化し, 電界が $1 \mu \mathrm{mV} / \mathrm{cm}$ あるいは $0.1 \mu \mathrm{mV} / \mathrm{cm}$ になったときの電流值を臨界電流 $I_{\mathrm{c}}$ と定義してきた。さ らに永久電流モードを考察するような場合にはより低電界 での定義が必要となる。しかし実験技術上誘導起電力, 測 定環境からのノイズ等により数十 $\mathrm{nV}$ 以下の測定は一般的 には困難であるため, 低電界での臨界電流は磁気的な方法 で決められてきた。しかし輸送法による低電界での情報の 限界を知っておくことが重要であり, 最近では数 $10 \mathrm{pV}$ の

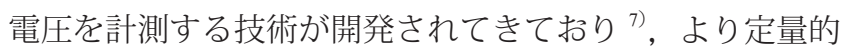
な議論がなされるようになってきている。例えば一定長さ のテープ状超電導試料の両端に電流端子を取り付け, その 内側に電圧端子を取り付け，いわゆる4 端子法で電流一電 圧特性を測定する状況を考えてみよう。Fig. 4 左は試料電 流がゼロ $(I=0)$ のときで YBCO テープの電圧端子間で測 定された電圧の時間依存性である。その電圧はゼ口を中心 にゆらいでいるがわかる。そのゆらぎの分布が右図に示さ れており，その半価幅は $56 \mathrm{pV}$ であった。試料電流がゼロ のとき, 試料が超電導状態にあれば電圧端子の平均電圧は ゼロと予想される。また電圧計までは銅線で繋がれており,
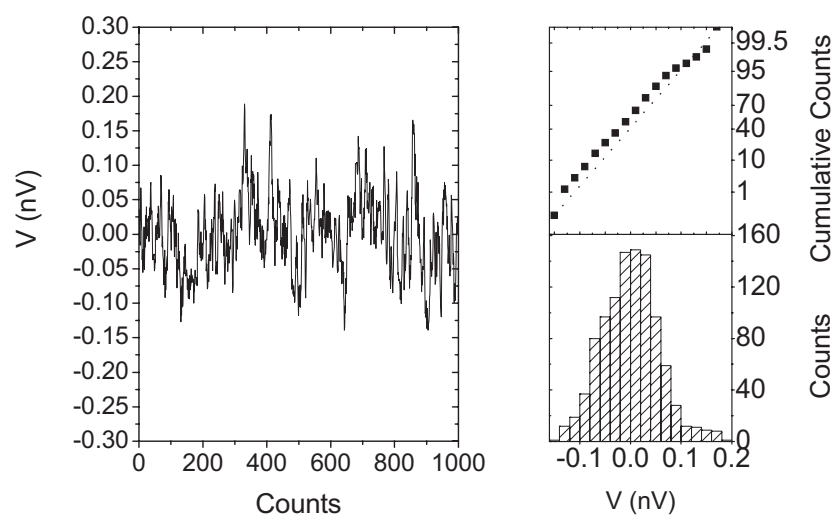

Fig. 4 Voltage fluctuations of the voltage taps and the HTS tape at $4.2 \mathrm{~K} . V_{\mathrm{RMS}}=56 \mathrm{pV}$.

TEION KOGAKU (J. Cryo. Soc. Jpn.) Vol. 44 No. 4 (2009) 
この間の常伝導状態にある銅線からは伝導電子の熱運動に よるいわゆる Johnson ノイズが発生しているので, 観測さ れる電圧ノイズ（ゆらぎ）はこれらの和と考えられる。

一方電圧端子を試料から取り外し短絡した時のいわゆ る Johnson ノイズは $25 \mathrm{pV}$ であったので, 超電導試料から の正味の電圧ノイズ成分は $21 \mathrm{pV}$ 程度であると考えられ る。さらに試料を磁場中に置くと，Fig. 5 に示されるよう に測定される電圧ノイズは磁場とともに増加する。磁場印 加によるノイズの増加には印加した磁場の不安定さが影響 するので，さらに詳細な測定が必要と考えられる。ここ で重要なことは輸送現象として少なくとも数 $10 \mathrm{pV}$ から数 $100 \mathrm{pV}$ の電圧ノイズが $4.2 \mathrm{~K}$ においても発生していること である。その本質の検討は今後の検討に待たれている。さ らに臨界温度より高温で擬ギャップ温度を通過するとき電 圧ノイズがどのように変化するか興味は尽きない。

また別に最近試料の局所的な欠陥，塑性加工による微小 な不均質性が，特異な形で数 $10 \mathrm{nV}$ 以下の低電界領域に出 現するかどうか検討が行われた ${ }^{8)}$ 。局所的な欠陥を有する 試料からの電流一電圧特性は,いわゆる加算則で説明でき, 一方塑性変形や磁場印加のような試料全体で起こる特性の 劣化はひとつの指数関数で表わすことができることが明ら かにされている。以上のように低電界領域での電圧ノイズ の発生について定量的な測定のめぞが立つようになり，こ の領域で新しいサイエンスが展開されることが期待され る。

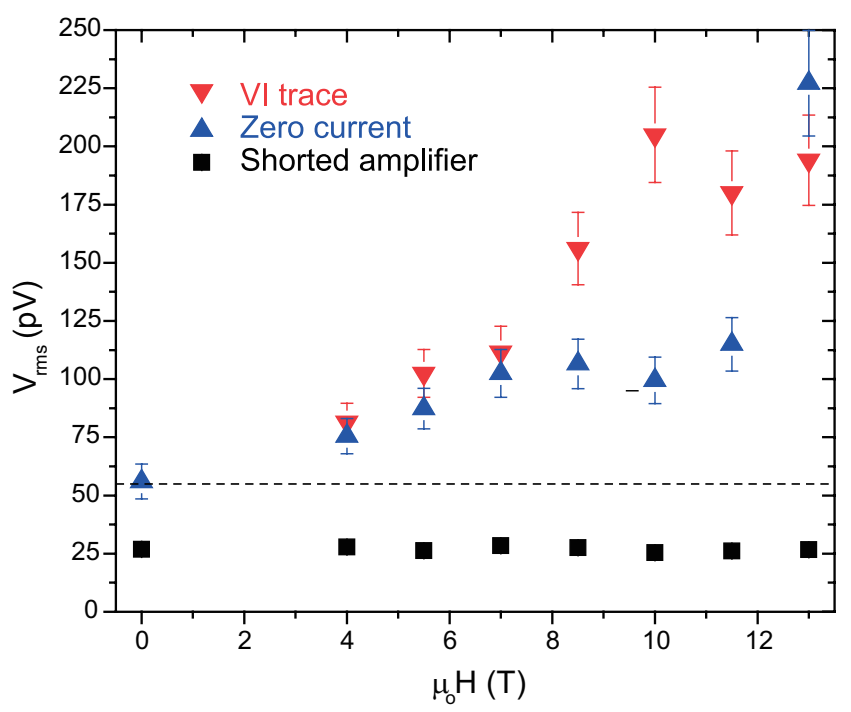

Fig. 5 Voltage fluctuations as a function of magnetic field. The black data represent measurements of the amplifier shorted essentially the noise floor for the amplifier. The dashed line represents the theoretical Johnson noise limit associated with the noise from the voltage taps and the amplifier. The data $(\boldsymbol{\Delta})$ are from measurements of the HTS tape at $4.2 \mathrm{~K}$ and with zero applied tape current - the difference between the data $(\mathbf{\Delta})$ and the dotted line is essentially magnet noise. The data $(\boldsymbol{\nabla})$ are from the $V-I$ traces.

\section{4. 機械的性質}

実用超電導材料は複合材であるため, 複雑な変形挙動を 示す。機械的変形には分類すると一軸性の引張, 圧縮, 引 張と圧縮が同時に作用する曲げ歪, さらに複雑なねじり歪 等々があり, 工学的にはねじり等の複雑な変形挙動の解明 が求められているが，現実には複合材料である超電導線の 定量的で厳密な理論解析は一軸性の引張抢よび圧縮に適用 されるに過ぎない。応力の測定は比較的簡単であるが, 歪 の正確な計測はかなり難しい。線状あるいはテープ状の試 料では Nyilas の伸び計を用いて引張歪を正確に測ることが できるが, 圧縮歪は試料が不安定に変形するため測定が困 難である。圧縮歪は後述する Walter spring 法, Uベント法 ${ }^{9}$, 4 点ビーム法 ${ }^{10)}$ 等で測ることができるが，いずれも歪の 絶対值を直接には求めることはできない。Nyilasの対称型 の伸び計の特徵は重量が $3 \mathrm{gr}$ 程度と軽量で高感度であるこ とである。Fig. 6 は $\mathrm{Nb}_{3} \mathrm{Sn}$ 多芯線材についての測定結果 ${ }^{11)}$ であるが，初期歪領域で絶対感度が数 $100 \mathrm{~nm}$ 程度の微小 変位の計測が安定して行われているのがわかる。さらに 2 軸の応力一歪特性の同時測定も比較的簡単で, その結果の 一例を Table 2 に示す。ただし軸方向は引張歪，径方向は

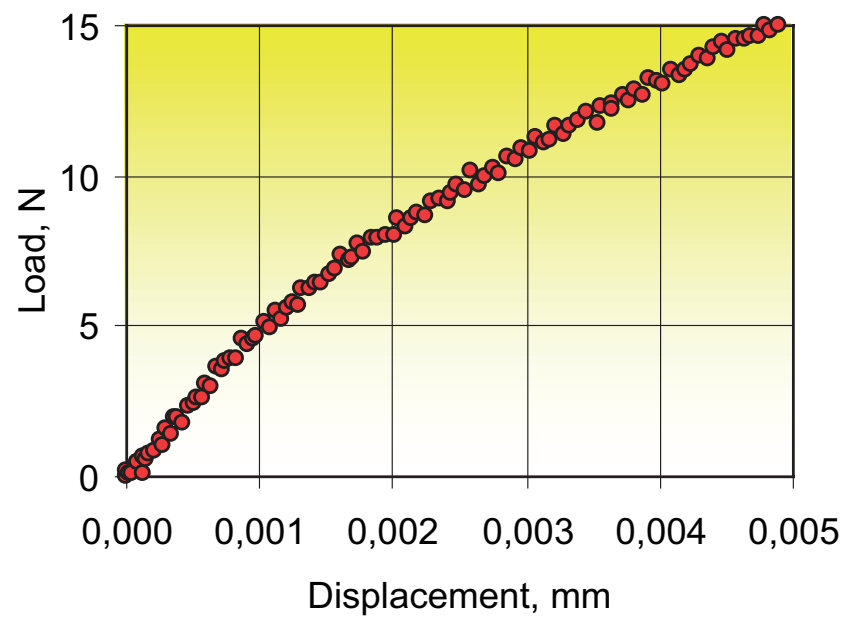

Fig. 6 Change of load as a function of displacement for $\mathrm{Nb}_{3} \mathrm{Sn}$ wire.

Table 2 Young's moduli along axial and radial directions and Poisson's ratio

\begin{tabular}{|c|c|c|c|c|}
\hline $\begin{array}{c}\text { SC material } \\
\text { and its diameter }\end{array}$ & $\begin{array}{c}T \\
(\mathrm{~K})\end{array}$ & $\begin{array}{c}E_{\text {axial }} \\
(\mathrm{GPa})\end{array}$ & $\begin{array}{c}E_{\text {diamental }} \\
(\mathrm{GPa})\end{array}$ & Poisson's ratio \\
\hline \multirow{2}{*}{$\begin{array}{c}\mathrm{Nb}_{3} \mathrm{Sn}(\mathrm{E}) \\
0.806 \mathrm{~mm} \phi\end{array}$} & 295 & 95 & 308 & 0.31 \\
\hline & 7 & 94 & 240 & 0.39 \\
\hline \multirow{2}{*}{$\begin{array}{l}\mathrm{Nb}_{3} \mathrm{Sn}(\mathrm{K}) \\
1.260 \mathrm{~mm} \phi\end{array}$} & 295 & 113 & 405 & 0.32 \\
\hline & 7 & 65 & 164 & 0.39 \\
\hline \multirow{2}{*}{$\begin{array}{c}\mathrm{Nb}_{3} \mathrm{Al}(\mathrm{J}) \\
0.818 \mathrm{~mm} \phi\end{array}$} & 295 & 132 & 506 & 0.26 \\
\hline & 7 & 67 & 244 & 0.27 \\
\hline
\end{tabular}


圧縮歪を示す。初期勾配の比からポアッソン比が求められ る。Table 3 に示したいくつかの線材の結果を比較すると, $\mathrm{Nb}_{3} \mathrm{Sn}$ の耐力より，2 種類の高温超電導線材のほうが大き いことがわかる。

ステンレス箔をラミネートした BSCCO 線材の応力一歪 曲線の一例を Fig. 7 に示す ${ }^{12)}$ 。変形挙動をいくつかの領 域に分類することができる。 $A_{\mathrm{el}}$ より小さな歪の領域 I で は純銀，半田は降伏して抢り，他の超電導フィラメント， SUS 䇴は弾性領域にあると考えられる。その勾配，つま り弾性定数は, 成分を BSCCO フィラメント $(i=1)$, 純銀 $(2)$, 銀合金（3），半田（4），SUS 箔（5）として

$$
E_{c}^{\mathrm{I}} \equiv \overline{E_{L a}}=E_{1} V_{f 1}+\omega_{2} E_{2} V_{f 2}+E_{3} V_{f 3}+\omega_{4} E_{4} V_{f 4}+E_{5} V_{f 5}
$$

で表わされる。ここで $E_{i}, V_{\mathrm{fi}}, \omega_{i}$ は $i$ 成分のヤング率，体積 分率，加工硬化係数である。また領域 II では銀合金が降 伏するものとして，その勾配は

$$
E_{c}^{\mathrm{II}}=E_{1} V_{f 1}+\omega_{2} E_{2} V_{f 2}+\omega_{3} E_{3} V_{f 3}+\omega_{4} E_{4} V_{f 4}+E_{5} V_{f 5}
$$

Table 3 Mechanical properties at room temperature for various $\mathrm{SC}$ wires

\begin{tabular}{|c|c|c|c|c|}
\hline $\begin{array}{c}\mathrm{SC} \\
\text { material }\end{array}$ & $\begin{array}{c}\text { Manufacturer and } \\
\text { structural feature }\end{array}$ & $\begin{array}{c}E \\
(\mathrm{GPa})\end{array}$ & $\begin{array}{c}R_{0.2} \\
(\mathrm{MPa})\end{array}$ & $\begin{array}{c}A_{0.2} \\
(\%)\end{array}$ \\
\hline \multirow{3}{*}{$\begin{array}{c}\text { BSCCO- } \\
2223\end{array}$} & SEI Insert & 85 & $(113)$ & $(0.15)$ \\
\cline { 2 - 5 } & SEI SUS3ply & 95 & 221 & 0.44 \\
\cline { 2 - 5 } & SEI Brass3ply & 88 & 246 & 0.50 \\
\hline \multirow{2}{*}{$\mathrm{YBCO}$} & AMSC 3ply & 122 & 369 & 0.49 \\
\cline { 2 - 5 } & SuperPower SCS & 144 & 840 & 0.79 \\
\hline \multirow{2}{*}{$\mathrm{Nb}_{3} \mathrm{Sn}$} & EAS Bronze & 113 & 187 & 0.38 \\
\cline { 2 - 5 } & Mitsubishi Internal Tin & 89 & 118 & 0.27 \\
\hline
\end{tabular}

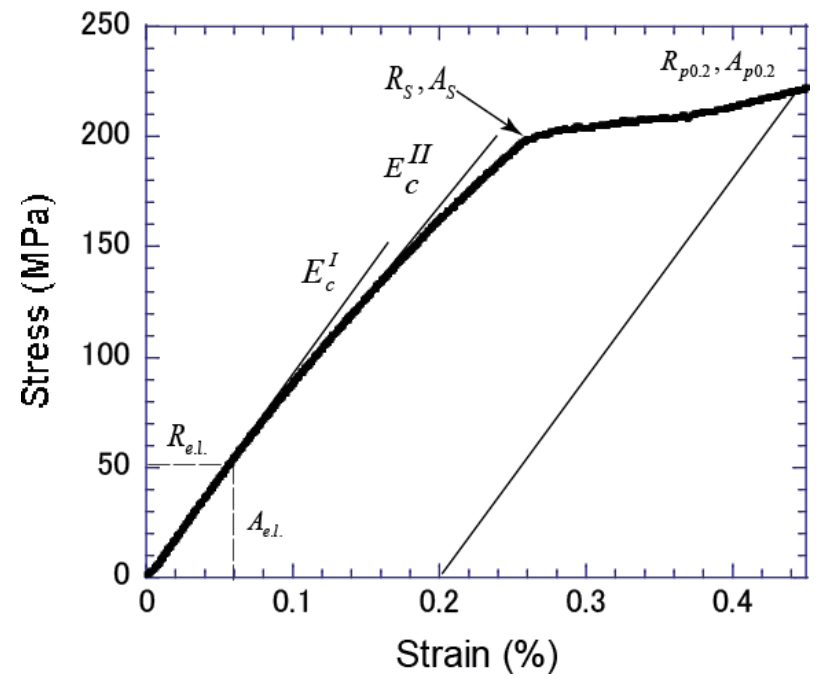

Fig. 7 Stress - strain curve for the BSCCO wire laminated with SUS tapes
Table 4 Comparison between observed and calculated mechanical properties for various $\mathrm{BSCCO}$ wires

\begin{tabular}{|c|c|c|c|c|c|c|c|}
\hline \multirow{2}{*}{$\begin{array}{c}\text { BSCCO } \\
\text { tapes }\end{array}$} & \multicolumn{2}{|c|}{$E_{\mathrm{c}}^{\mathrm{I}}(\mathrm{GPa})$} & \multicolumn{2}{|c|}{$E_{\mathrm{c}}^{\mathrm{II}}(\mathrm{GPa})$} & $e_{\mathrm{ff}}(\%)$ & \multicolumn{2}{|c|}{$R_{\mathrm{ff}}(\mathrm{MPa})$} \\
\cline { 2 - 8 } & obs & cal & obs & cal & cal & obs & cal \\
\hline HS & 93 & 92.8 & 75 & 74.7 & 0.090 & 75 & 77.1 \\
\hline Insert & 89 & 89.2 & 72 & 72.1 & 0.059 & 48 & 47.1 \\
\hline SUS3ply & 95 & 95.7 & 84 & 82.3 & 0.070 & 65 & 64.7 \\
\hline Brass3ply & 88 & 83.8 & 78 & 76.0 & 0.086 & 71 & 68.8 \\
\hline
\end{tabular}

で表わされる。Table 4 に，これらの式を用いて計算した 弾性定数が示されているが，実験值をよく説明する。この ように比較的簡単な理論的考察で全体の傾向を把握するこ とができる。ただし計算に用いる物質定数を正確に求めて 抢くことが肝要である ${ }^{13)}$ 。一軸性の圧縮荷重下の変形挙 動も上述と同様の考察が可能である。曲げ変形については 落合等が詳しく検討している ${ }^{14)}$ 。

\section{5. 臨界電流の応力・歪依存性}

臨界電流は歪（応力）に敏感である。試料に引張あるい は圧縮の応力を加えると臨界電流は変化する。応力をゼロ にしたとき臨界電流がもとに戻る可逆領域と, 戻らない不 可逆領域とがある。不可逆領域の出現は超電導層に何らか の久陥が生じて特性が劣化したことを意味する。一方, 詳 しくは後述するが, BSCCO 系では可逆領域でも引張歪と ともに単調に減少する ${ }^{15)}$ 。YBCO 系では A15 化合物のと きと同様に臨界電流の歪依存性は上に凸の山型になる ${ }^{16)}$ 。 これらの可逆領域での歪依存性の全体を総称して真性歪効 果と呼ぶことにすると, $\mathrm{BSCCO}$ 系では数 \%, YBCO 系で は大きいと $10 \%$ 程度の臨界電流の減少となる。次に試験 方法とともに，その詳細について検討する。

\section{1 一軸引張歪依存性}

引張荷重側のみに限られるが，Nyilasの伸び計を用いた 臨界電流の一軸引張歪依存性の計測は定量性のある実験 手法である。Fig. 8 は引張荷重下における臨界電流測定の 代表的な装置の一部である。引張試験機の絶縁された銅 チャックから試料に最大 $500 \mathrm{~A}$ の電流を流すことができ る。この部分は液体窒素に浸されており, 引張荷重が印加 された試料の歪は Nyilas の伸び計で測定し, 同時に $E-I$ 特 性を計測する。結果の一例を Fig. 9 に示す ${ }^{177}$ 。ここで縦軸 は臨界電流 $I_{\mathrm{c}}$ を極大 $I_{\mathrm{cm}}$ で規格化したもので, 横軸はひず み A（\%) である。一定の歪を与えて臨界電流測定して丸 印のようにプロットする。たとえば点 $\mathrm{G}$ まで歪ませた後, 引張荷重を開放して臨界電流を測定し， 口印のように示 す。点 $\mathrm{G}$ から戻った点を $\mathrm{H}$ とする。このようにして引張 荷重後, 除荷したとき臨界電流がどこまで回復したかを調 べる。Fig. 9 の $\mathrm{A}<0.1 \%$ の歪範囲では明らかに臨界電流は

TEION KOGAKU (J. Cryo. Soc. Jpn.) Vol. 44 No. 4 (2009) 


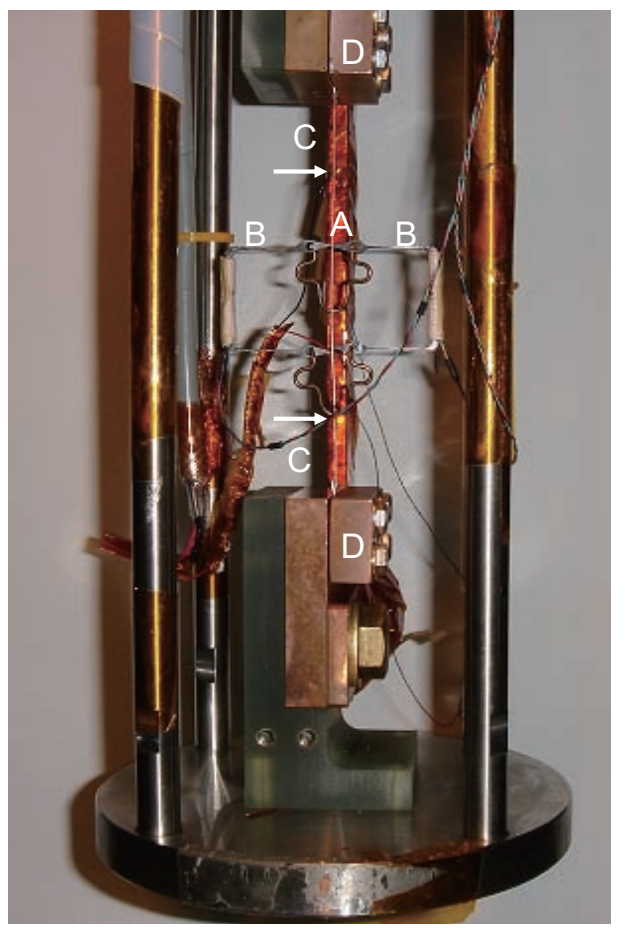

Fig. 8 Apparatus for measuring the critical current under tensile load in the liquid nitrogen, where A, B, C and D are the sample, extensometer, voltage tape and current terminal.

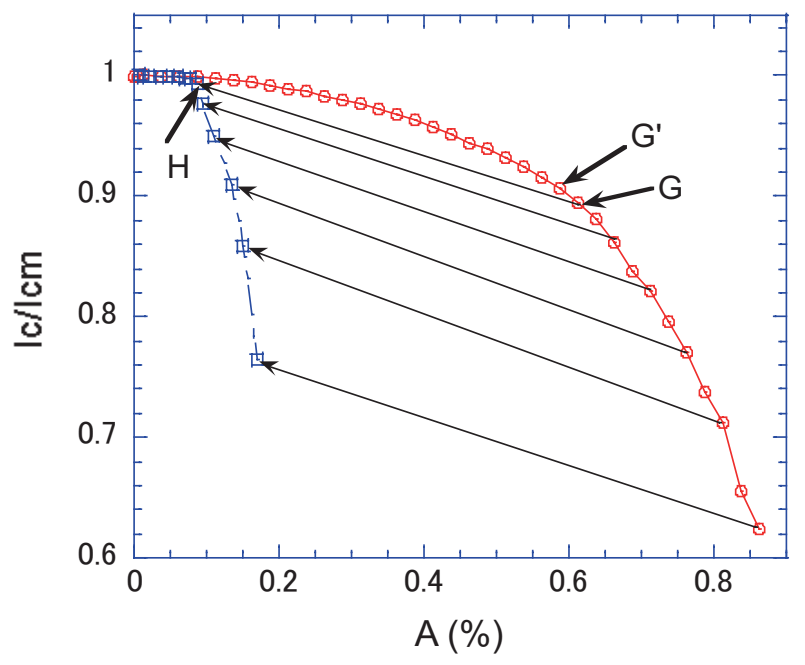

Fig. 9 Strain dependence of the normalized critical current for SuperPower-YBCO coated conductor.

回復している。このような可逆性の範囲の限界として点 $\mathrm{H}$ で臨界電流が 99\% 戻ったときの点 $\mathrm{G}$ の歪を可逆限界歪と 定義することにする。なお図中の $G^{\prime}$ は $99.5 \%$ 回復に相当 する。つまりこれら限界歪より大きな歪領域まで変形する と YBCO 超電導層は脆性破断を起こす ${ }^{18)}$ 。

Fig. 10 はラミネートした BSCCO 線材の例である ${ }^{19)}$ 。こ こで外部ひずみがゼロでの臨界電流の值を $I_{\mathrm{co}}$ として, 臨 界電流を規格化した $I_{\mathrm{c}} / I_{\mathrm{co}}$ がプロットされている。可逆歪 領域内では臨界電流はわずかずつ単調減少していることが わかる。これらの可逆限界歪限は Table 5 にまとめて示し

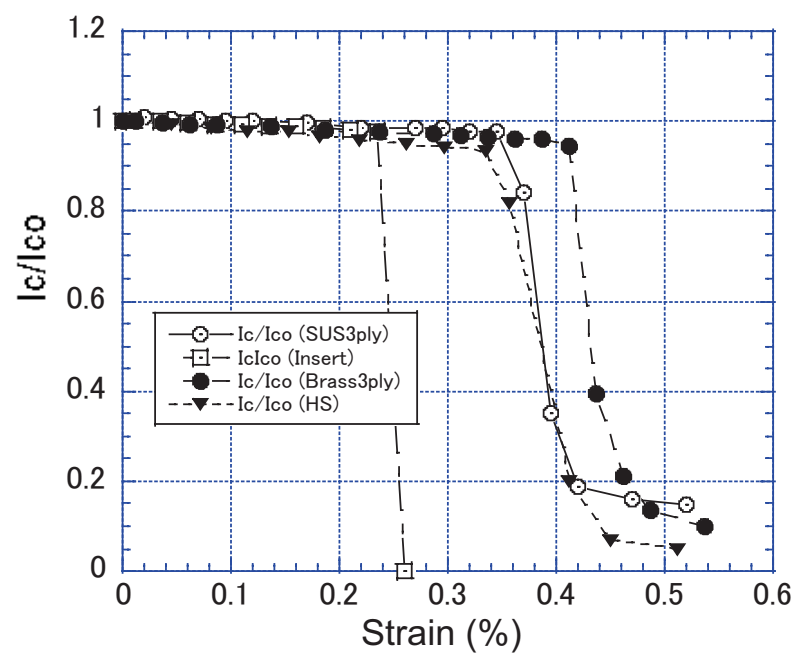

Fig. 10 Strain dependence of the normalized critical current for various BSCCO tapes.

Table 5 Reversible strain (stress) limits $\left(R_{99 \%}, A_{99 \%}\right)$ for various HT superconductors

\begin{tabular}{|c|l|c|c|}
\hline $\begin{array}{c}\text { SC } \\
\text { material }\end{array}$ & $\begin{array}{c}\text { Manufacturer and } \\
\text { structural feature }\end{array}$ & $\begin{array}{c}R_{99 \%} \\
(\mathrm{MPa})\end{array}$ & $\begin{array}{c}A_{99 \%} \\
(\%)\end{array}$ \\
\hline \multirow{3}{*}{ BSCCO-2223 } & SEI Insert & 126 & 0.21 \\
\cline { 2 - 4 } & SEI Brass 3ply(50) & 307 & 0.45 \\
\cline { 2 - 4 } & SEI SUS 3ply(20) & 282 & 0.39 \\
\hline \multirow{2}{*}{ YBCO } & AMSC Cu3Ply & 507 & 0.50 \\
\cline { 2 - 4 } & SuperPower SCS & 978 & 0.70 \\
\hline
\end{tabular}

たが，この限界歪はラミネートによって著しく増加するこ とが明らかである。ここで表中の第 2 列のカッコの中の数 字はラミネート層の厚さを $\mu \mathrm{m}$ 単位で表したものである。 可逆な弾性域から脆性的な領域への境界は, BSCCO 線材 では経験的に 95\%retention $I_{\mathrm{c}}$ で決められてきたが，これは 明かに脆性的な領域に入り込んでおり，むしろ可逆的な限 界点を求めることが必要になってきた。実験的な精度も 考慮して $99 \% I_{\mathrm{c}}$ が回復する点を可逆限界歪とした。一方 $\mathrm{Nb}_{3} \mathrm{Sn}$ 線材では，99\% $I_{\mathrm{c}}$ 回復という明確な基準で測定した 例はないが，超電導フィラメントにクラックが観察され始 めるのは, ブロンズ法線材では $0.7 \%$, 内部錫法線材では $0.3 \sim 0.4 \%$ との外部歪に対応することが報告されている ${ }^{20)}$ 。

\subsection{Walter spring 法}

磁場，応力が同時に作用する環境中での臨界電流測定方 法には種々の工夫があるが, Walter spring（WASP）法では

Fig. 11 に示すような試料ホルダーに線材を巻きつけて固 定し, 軸回転することにより, 試料に引張, 圧縮の歪を与え, 臨界電流を測定するものである ${ }^{21)}$ 。WASP 法におけるひず み負荷原理は, スプリング状の治具の外周に線材を固定し, スプリングにねじり変形を与えることによって線材に軸方 向の引張または圧縮のひずみを加えるというものである。 また, WASP 法の長所は引張, 圧縮の両側の測定が可能で 


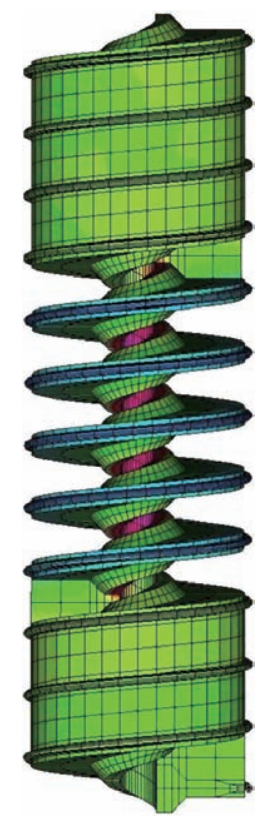

Fig. 11 Design of Walter spring, where the sample is soldered on the outer edge.

あること，電圧端子間距離を長く取れることから低電界部 分まで評価可能であることでる。一方，スプリングに固定 する過程で線材が曲げ変形を受けることや冷却時に治具の 収縮が影響を及ぼすことから，測定データのひずみのゼ 口点を決定するのが難しいという短所がある。Hampshire らのグループでは磁場範囲 $3<B<27 \mathrm{~T}$, 温度範囲 $2 \mathrm{~K}<T<$ $T_{\mathrm{c}}$, 歪範囲 $-1.0 \%<A<0.8 \%$, 電流 $I<600 \mathrm{~A}$, 電圧 $V>1$ $\mathrm{nV}$ のような条件での測定装置を開発している。

菅野らの YBCO 線材についての結果を Fig. 12 に示 す ${ }^{22)}$ 。図には, 短尺テープ状サンプルの測定結果も “uniaxial tensile” として同時にプロットしている。あらかじめ巻き 線固定するときに圧縮 (引張) 曲げを負荷することにより, 曲線のピークが引張 (圧縮) 側にシフトしていることがわ かる。また，引張，圧縮の両ひずみ領域について測定を行 うことにより， $I_{c}$ がひずみに対してパラボリックに変化し ている傾向が確認されている。

\section{3 曲げ歪法}

Fig. 13 は Bi2223 テープ線材曲げ試験法（サンドイッチ 方式）の模式図で，この方法を確立するため，各国から 11 の研究機関の参加を得て, 臨界電流を曲げ歪の関数と して国際ラウンドロビンテストが実施された ${ }^{23)}$ 。その解 析結果から曲げ負荷の与え方，試料の固定方法，電流端子 固定法，ハンダの材質などの影響が明かにされ，結果とし てデータのばらつきは，試料中に存在する不均一性および ハンダ付けなどにより測定中に導入される種々の歪による ことが明らかになった ${ }^{24)}$ 。また計算機シュミレーション によりその統計的背景が明らかにされた ${ }^{25)}$ 。また 2 点支 持式で連続的に曲げ歪を与えることのできる Goldacker 法 による結果との比較も行われた。

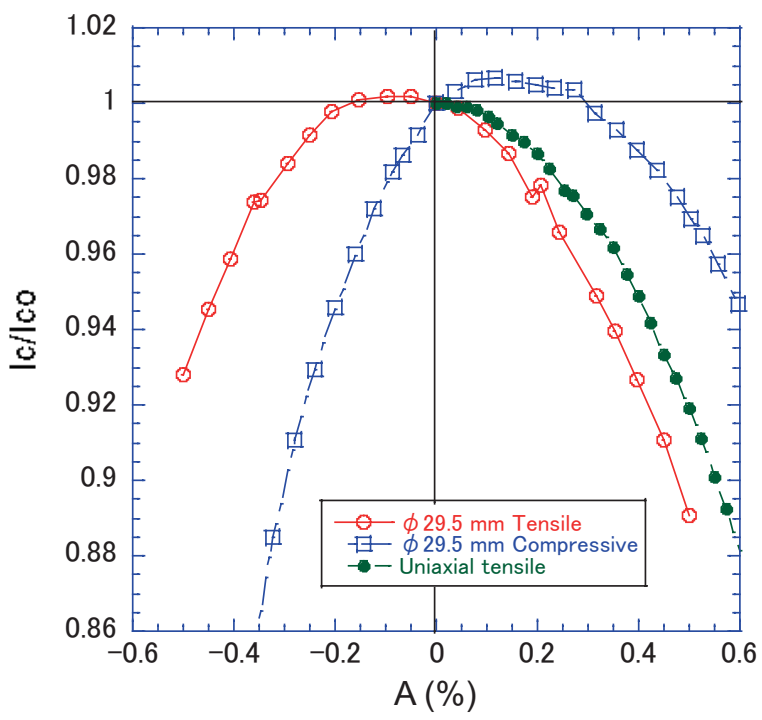

Fig. 12 Strain dependence of critical current measured by means of WASP technique for YBCO coated conductors, where the tensile and compressive indicate that the tapes were bent outwards and inwards when they were mounted on the spring. The uniaxial tensile indicates the result tested by using the straight tape.
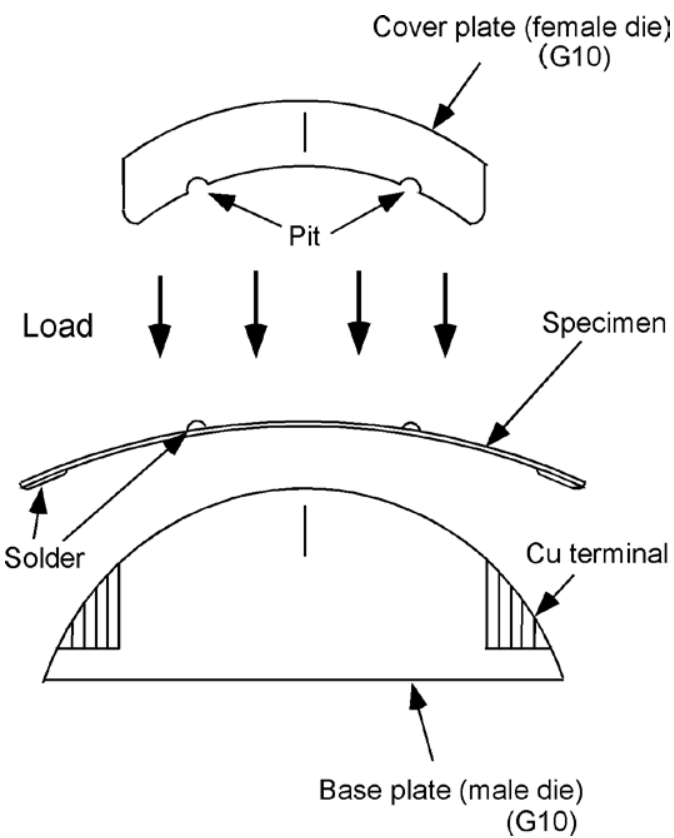

Fig. 13 Device measuring the bending strain dependence of critical current.

\section{6. 量子ビームを用いた局所歪の測定}

回折現象を用いた実用超電導線材の組織の評価法とし て，YBCO 線材については $\mathrm{c}$ 軸配向，面内配向の評価は通 常のラボ実験で非破壊的に行われて，結晶配向性を定量的 に評価する方法はほぼ確立している。これは超電導層を覆 う保護層の厚さが薄いので X 線が有効に通過できる条件 があるためである。しかし YBCO 線材といえども，テー プ軸方向の歪を測定すること，あるいは一般的に BSCCO, 
$\mathrm{MgB}_{2}$ 線材の結晶配向性，歪の測定はそれほど簡単では ない。このような場合には輝度の高い放射光や透過能の 大きな中性子のような量子ビームの利用が有効である。 BSCCO 線材の配向性評価についてはすでに述べたが，こ こでは超電導層中の歪測定とその結果について述べる。

測定そのものは，特定の回折線を精密に測定することで あり，Fig. 14 に示すように測定值に対してガウス関数を fitting し, その中心值から平均の格子定数を求める。相対 測定精度は経験的なものであるが，放射光で $0.001 \%$ ，中 性子で $0.005 \%$ 程度である。

実用超電導材料の特徴の一つは複合体であるということ であり，そのため成分による熱膨張係数の違いから各成分 には不可避的に熱残留歪が存在する。たとえばラミネート された BSCCO 線材では超電導フィラメント（成分 1）中 の熱残留歪 $A_{\mathrm{r} 1}$ は次式のようにかなり良い近似で ${ }^{12)}$,

$$
A_{r 1} \cong \frac{\left(\alpha_{3}-\alpha_{1}\right) E_{3} \overline{V_{f 3}}\left(T-T_{o}\right)+\left(\alpha_{5}-\alpha_{1}\right) E_{5} V_{f 5}\left(T-T_{B}\right)}{\overline{E_{L a}}}
$$

と表わされる。ここで $E_{\mathrm{i}}$ はヤング率， $\alpha$ は熱膨張係数， $V_{\mathrm{f}}$ は体積分率， $T_{\mathrm{o}}, T_{\mathrm{B}}$ はそれぞれ歪が集積し始める温度，接 合温度である。成分 3 と 5 は銀合金抢よびラミネート金属

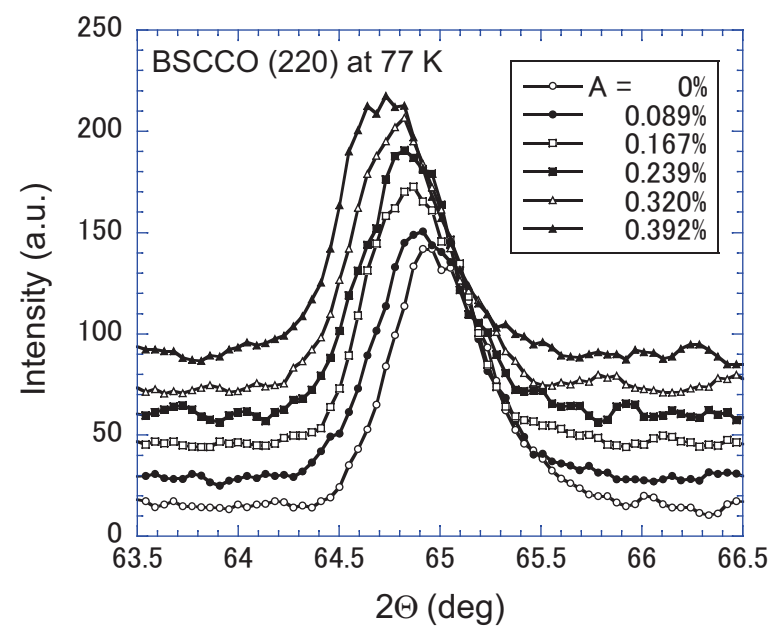

Fig. 14 Shift of BSCCO (220) diffraction peak when the tensile load was applied at $77 \mathrm{~K}$ for BSCCO tapes. The corresponding strain is indicated in the figure.
を示す。BSCCO の熱膨張係数は銀，銅，SUS 等の金属合 金のそれと較べると小さいため, BSCCO に残留する内部 歪は（3）式から負であることがわかる。つまり周りの金 属成分から圧縮を加えられた状態にある。

実際にどの程度の圧縮歪が残留するか計算結果および中 性子回折を用いて測定した結果を Table 6 に示す ${ }^{19)}$ 。室温 での結果を比較すると, Insert 材を除いて計算值と実測值 は一致する。さて試料を引張れば伸びるわけであるが，そ の引張歪を $A$ で示せば, 超電導線材中の超電導成分内の 実質の歪, つまり真性歪 $A_{i}$ は

$$
A_{i}=A_{r 1}+A=A-A_{f f}
$$

で示される。ここで引張歪 $A$ が丁度 $-A_{\mathrm{ri}}$ になったとき真 性歪は $A_{i}=0$ となる。これは超電導フィラメントに加わっ ている圧縮の応力が引張りの応力に変わる丁度内部応力 がゼロになる歪であり，ここでは “force free strain” $A_{\mathrm{ff}}$ (= $\left.-A_{\mathrm{r} 1}\right)$ と呼ぶことにする。前節で可逆限界歪 $A_{99 \%}$ について 説明したが，この限界歪を越えると超電導成分が脆性破断 を起こし始める。この真性破断歪 $A_{\mathrm{if}}$ は

$$
A_{i f}=A_{99 \%}-A_{f f}
$$

で表わせることになる。真性破断歪は超電導フィラメント 中の破断に至る引張成分を示すが，Table 6 に示すように， この值はラミネーションにより 2 倍以上に増加する。

超伝導層中の歪状態についてまとめると, 熱処理温度か ら冷却後の状態では圧縮の熱残留歪が存在し, 外部からの 引張荷重の印加とともに, 超伝導層内の応力がゼロになる 歪（force free strain）を越えさらに荷重をかけると可逆性 が失われフィラメントの破断 ${ }^{19)}$, 臨界電流密度が急激に減 少し始める不可逆歪領域に入る。ここで Table 6 で insert 材 の室温で測定される残留歪が小さいのは, 銀, 銀合金の回 復が起こったためであると推測される。すなわち BSCCO テープ材の高性能化のための因子としては（i）臨界電流の 歪依存性の観点からは $A_{\mathrm{ff}}$ の值をいかに大きくするか，そ のため（3）式を参考に熱膨張係数, 弾性定数を考慮した 材料選択を行う。（ii）Table 6 の真性破断歪の值はラミネー トすることにより大きくなる。つまり複合体の高強度化の

Table 6 Compressive residual strain $\left(A_{\mathrm{r} 1}\right)$, reversible strain limit $\left(A_{99 \%}\right)$ and intrinsic fracture strain $\left(A_{\text {if }}\right)$ exerted on SC filaments in the BSCCO wire

\begin{tabular}{lccccc}
\hline \hline \multirow{2}{*}{ Sample } & \multicolumn{2}{c}{ Calculation } & Experiments & & $A_{99 \%}$ \\
\cline { 2 - 4 } & $\begin{array}{c}A_{\mathrm{r} 1} \text { at RT } \\
(\%)\end{array}$ & $\begin{array}{c}A_{\mathrm{r} 1} \text { at } 77 \mathrm{~K} \\
(\%)\end{array}$ & $\begin{array}{c}A_{\mathrm{r} 1} \text { at RT } \\
(\%)\end{array}$ & $\begin{array}{c}A_{\text {if }} \\
(\%)\end{array}$ & $(\%)$ \\
\hline Insert & -0.055 & -0.099 & -0.008 & 0.206 & 0.107 \\
Brass50 & -0.081 & -0.146 & - & 0.445 & 0.299 \\
Brass100 & -0.088 & -0.158 & -0.1098 & 0.424 & 0.266 \\
Sn bearing Cu50 & -0.053 & -0.095 & -0.0820 & 0.362 & 0.267 \\
SUS20 & -0.052 & -0.094 & -0.0895 & 0.389 & 0.295 \\
\hline
\end{tabular}


観点から補強層を加えることにより複合体の弾性定数を高 め, さらに耐力を高めるかといったことが大切な材料設計 の指針になる。

次に BSSCO 線材中の超電導フィラメントの内部歪が加 工熱処理によりどのように変化するか，シミュレーション の結果を説明する。AMSC 社のインサートテープと，それ をインサート材としてステンレス鋼とラミネート複合した ラミネート複合テープについての結果であり，ラミネート 温度は $453 \mathrm{~K}$ であった ${ }^{26)}$ 。両試料とも臨界電流確認のため AMSC 社で一旦 $77 \mathrm{~K}$ に冷却され，室温に戻された後，外 部の研究者に送られている。両テープ中の Bi2223 フィラ メントの試料長さ方向の残留歪は, SPring 8 ・ビームライ ン 46XU で評価された ${ }^{27,28)}$ 。この一連の加工熱処理のプロ セスでの Bi2223 フィラメントのひずみ変化を Fig. 15 に示 す。インサートテープ中の Bi2223 は ABCDEFGHEFG，ラ ミネート複合テープ中のそれは ABCDIJKJLMNOPQROPQ と変化する。このように両者では複合化後のひずみ量の差 は大きく異なり，特に低温で大きくなる。77 K ではラミ ネート化によって約 2 倍の圧縮ひずみになる。実はこの 一連のプロセスの最後の点 $\mathrm{G}$ および $\mathrm{Q}$ で X 線回折により Bi2223 フィラメントの室温での残留歪が, インサートテー プでは $-0.049 \%$ ，ラミネート複合テープは $-0.133 \%$ である ことが求められた。このことにより Fig. 15 に示すように, すべての時点での歪の值を決定できたわけである。この計 算で未知值であった，高温のどの温度（B 点に相当）から 歪が蓄積され始めるかが，すなわち $T_{\mathrm{B}}=563 \mathrm{~K}$ と決定され た。

YBCO 線材において超電導層中の内部歪が引張荷重下で ぞのように変化するのか，室温で $i n-s i t u$ 測定した結果を Fig. 16 に示す ${ }^{17)}$ 。応力一歪曲線をみると，矢印の付近か ら勾配が徐々に減少しはじめる。つまり弾性域から微小降

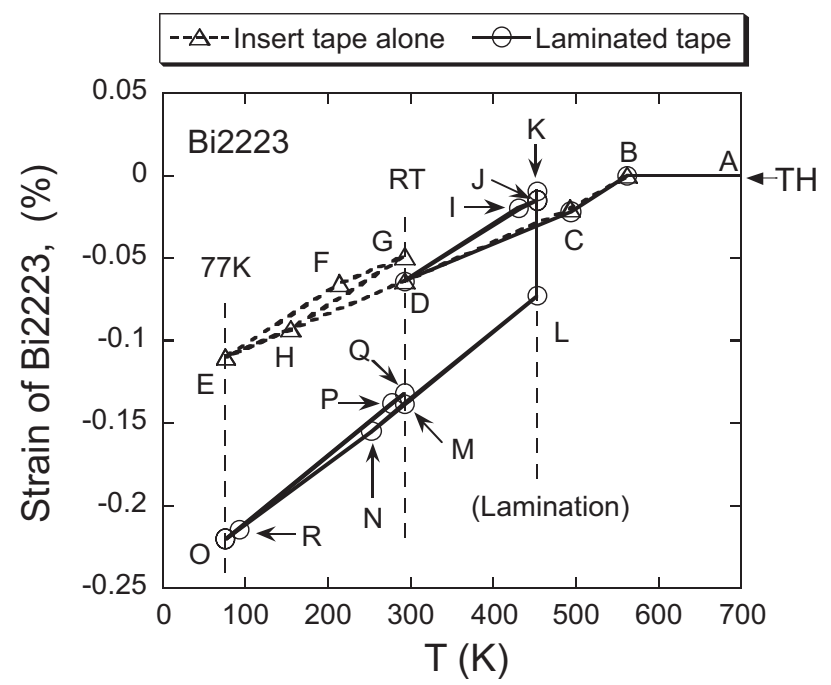

Fig. 15 Change of internal strain exerted on the BSCCO filaments during the heat treatment process.

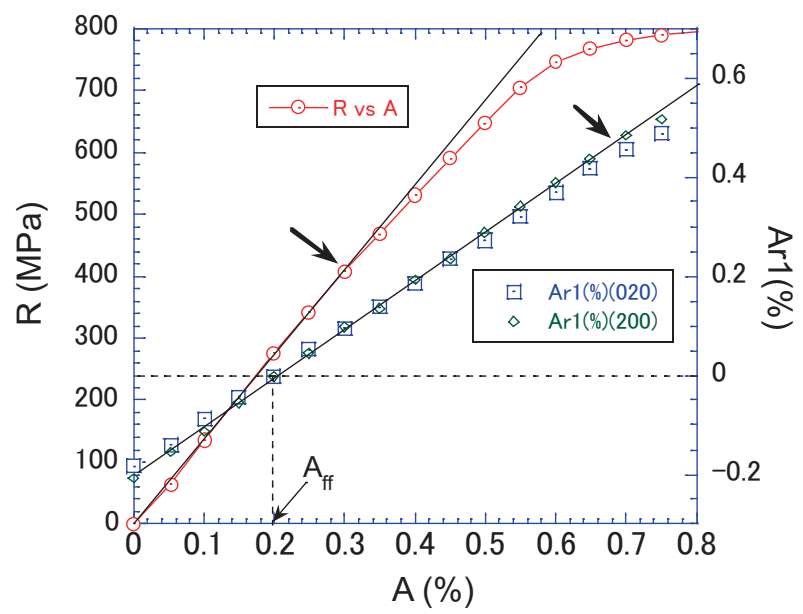

Fig. 16 Change of internal strain exerted on the YBCO layer as a function of applied strain and the stress-strain curve for the YBCO coated conductor by SuperPower.

伏の領域 ${ }^{27)}$ に入ったことを示す。巨視的な降伏の目安と なる $0.2 \%$ 降伏点は $R_{0.2}=795 \mathrm{MPa}, A_{0.2}=0.78 \%$ となる。一方 超電導層中の内部歪は, 外部歪ゼロのとき $-0.2 \%$ つまり 圧縮歪の状態にある。外部からの引張歪とともに，引張成 分が加わり, $A_{\mathrm{ff}}=0.2 \%$ でゼロとなる。その後は超電導層中 の内部歪は引張成分となり増加する。ほぼ矢印で示す歪ま で直線的に変化している。これは弾性的な挙動であり，こ の矢印より歪が大きくなると直線より下にずれるようにな る。このことは脆性的な破断が起こったことを示すもので ある ${ }^{29)}$ 。このように重要なことは超電導線材中の超電導 層の変形・破壊挙動と巨視的な複合体の機械的性質とを実 験的に関連付けられるようになったことである。

YBCO 線材の臨界電流の歪依存性について最大の関心 事は臨界電流の極大にまつわる, いわゆる真性歪効果につ いてである。Fig. 17 はいくつかの YBCO 線材の臨界電流 の歪依存性を示している。ここで $a, b, A_{\text {max }}$ は（7）式中で 用いられる定数である。一般に臨界電流の值に極大が出 現する。その最大歪は Table 7 の $A_{\max }$ として示されている が，その他の YBCO 線材に打いても $0.01 \%$ から $0.4 \%$ の広 い範囲に分布している ${ }^{30)}$ 。現在のところこの変動と, 基 板や結晶成長法等の製造方法との相関はまだ明らかにされ ていない。一方 $\mathrm{Nb}_{3} \mathrm{Sn}$ 線材で以前から知られているように, この真性効果の歪依存性は

$$
I_{c} / I_{c \max }=1-a\left|\left(A-A_{\max }\right)\right|^{b}
$$

で表わされることができる。ここに $a, b$ は定数である。本 解説ではこの臨界電流最大を示す効果を「Ekin の真性歪 効果」と呼ぶことにする。Fig. 17 の曲線で表され, 可逆 歪領域では実測值をよく説明している。これまでの $\mathrm{Nb}_{3} \mathrm{Sn}$ に扔ける理論的考察に扔いて, $A_{\max }$ で超電導層の内部歪は ゼロ，すなわち $A_{\max }=A_{\mathrm{ff}}$ であるとされてきた。しかし液体 窒素温度での $A_{\mathrm{ff}}$ は Table 7 に示されている室温での值より

TEION KOGAKU (J. Cryo. Soc. Jpn.) Vol. 44 No. 4 (2009) 


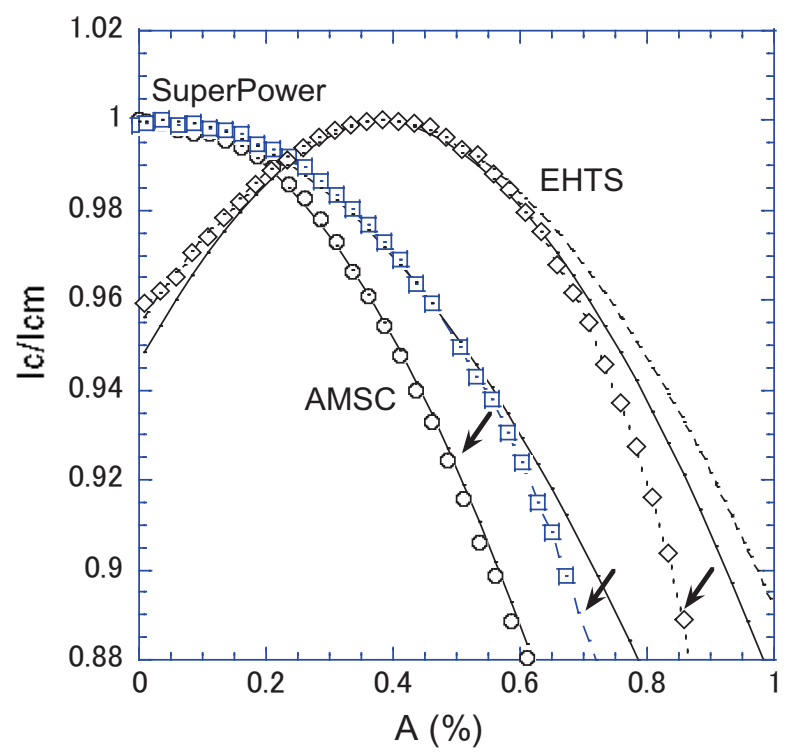

Fig. 17 Strain dependence of the normalized critical current in the reversible strain region for various YBCO coated conductors, where the arrows indicate each reversible strain limit.

Table 7 Analysis of "Ekin's intrinsic strain effect"

\begin{tabular}{|l|c|c|c|c|}
\hline $\begin{array}{l}\text { Manufaturer and its } \\
\text { structural feature }\end{array}$ & $a$ & $b$ & $\begin{array}{c}A_{\max } \\
(\%)\end{array}$ & $\begin{array}{c}A_{\mathrm{ff}} \text { at RT } \\
(\%)\end{array}$ \\
\hline AMSC Cu3ply & 1700 & 1.9 & 0.075 & 0.15 \\
\hline SuperPower SCS & 1300 & 1.9 & 0.035 & 0.20 \\
\hline EHTS & 1200 & 1.8 & 0.38 & - \\
\hline
\end{tabular}

さらに $0.1 \%$ は大きいと考えられる。すなわち少なくとも 実測值のある2つの線材では $A_{\text {max }}$ と $A_{\mathrm{ff}}$ は等しくない。今後, 液体窒素温度で実際に $A_{\mathrm{ff}}$ を測定して $A_{\text {max }}$ との一致, 不一 致を検証することは, 学問的にも, 工学的にも重要なこと と考えられる。

\section{7. おわりに}

平成 17 年 10 月から平成 19 年 9 月の期間に NEDO Grant (応用超電導) の下に国際共同研究を行われた。この国際 共同研究の目的は 1）三大機能を最大化した高性能・低コ スト超電導材料の設計と最適な材料の開発に関して提言と 指針を示す，2）材料開発と表裏一体となる特性評価技術 の高度化を図ることであった。本解説は，そのときの研究 成果をもとに, さらに平成 20 年 5 月の低温工学・超電導 学会春季講演大会での講演内容および, その後の研究の発 展につても多少加えて, 機械・電磁気特性を中心にまとめ たものである。

今後の工学的目的から, 超電導線は一般的に小さな断面 積であるが，1 kmに及ぶ長尺の線として使われる。しかも 長尺にわたりその複雑な複合構造も外形的形態も均質で, 超電導特性並びにその他の性質においても均質でなければ
ならない。一般に均質さ，一定さの評価については平均值 からの分散あるいは不確定さが実験的に求められる指標と なる。不均質さには統計的なものと, 偶発的なものとがあ る。BSSCO 線材でいえば, 非超電導相や配向性等は空間 的に分布し, それが結果的に臨界電流密度の分散に影響す る。一方窒素ガスのバブリングは非常に稀に観察される。 前者の統計的な不均質さについては, どの程度の範囲にわ たり検査すれば超電導線全体の特徵を代表するかはワイブ ル統計分布の概念を適用することにより理論的に明かにさ れ, それに従い試験することが求められる。原因となる微 視的構造を分析し, 統計データとの相関を調べることが, 製造工程の改善の近道になるのではないかと考えられる。

超電導線材の 3 大機能として, 工学的臨界電流密度, 機 械特性等はかなり実用化に近いレベルに達しつつある。一 方交流損失については，その低減について種々の提案がな されているが, 長尺線の実現にはまだ時間がかかるようで ある。もう少しこの分野に研究資源を集中して解決をはか ることが, 超電導技術全体の発展に必須のことのように思 われる。Nb-Ti を除いて，すべての工学的超電導材料は金 属間化合物あるいは酸化物等であり, 非常に脆性的である。 これを金属基材と複合化して，その欠点を克服しょうとし ているわけである。本解説でも機械的にどの程度で劣化す るか，たとえば可逆限界歪を定義し，その共通の測定方法 で各種超電導材料を評価してきた。このような客観的な特 性の比較は工学的応用のために材料を選択するため重要で ある。さらに超電導電力応用技術が地球環境問題への対応 およびエネルギーセキュリティーの確保に対して貢献でき る技術となるためには, 経済活動における技術的手段とし て選択される必要がある。すなわち, 性能はもとより経済 的側面においても魅力的であることが必要不可欠である。 とくに超電導線材の特性が, 従来の銅と鉄の特性を活用し た電力機器を大きく凌駕する魅力がなければ, 超電導技術 の導入と浸透は難しい。個別の電力機器に拈いて超電導線 材に求められる条件はそれぞれに異なるので, それらの使 用条件で特性が最大限発揮できるかを意識しつつ開発し, それを明示することが必要である。たとえば，どの程度の 工学的臨界電流密度とその対歪特性が必要か, 過剩な仕様 を求めるのではなく, 適正な範囲の仕様を基準に, 総合的 に超電導材料を選択することが，今後は求められると考え られる。そのためには評価方法の標準化, データの系統的 な収集といったことの必要性が高まるものと考えられる。

最後になりますが，本解説を書くよう励ましをいただき ました低温工学編集委員会には, このような機会を与えて いただきました光栄を心から感謝しております。また執筆 中, ご助言をいただきました物材機構 黒田恒生, 原研 辺 見勉, ASC-NHMFL Eric Hellstrom の各博士には, ここに 厚く打礼申し上げます。 


\section{参考文 献}

1) S. Akita: "General discussion on the trend and future of electric power generation, transmission and distribution, and role of SC technologies - Direction of R\&D of SC materials-", Abstracts of CSJ Conference 78 (2008) 191（in Japanese）

秋田 調:「発送配電技術の動向と超電導技術の役割一超 電導材料の研究開発動向を鍵として一」, 第 78 回 2008 年 度春季低温工学・超電導学会講演概要集 (2008) 191

2) K.Osamura: "Three major characteristics of high temperature composite superconductors”, TEION KOGAKU 42 (2007) 124130

長村光造 : 「高温超電導複合材料の 3 大機能 $」$, 低温工学 42 (2007) 124-130

3) S Machiya, K Osamura, H Suzuki, T Kato, N Ayai, K Hayashi and K Kato: "In situ strain measurements by neutron diffraction and residual stress estimation in Ag-sheathed Bi2223 superconducting composite tapes", Supercond. Sci. Technol. 21 (2008) 054007 (6pp)

4) N. Ayai, K. Kato, J. Fujikami, S. Kobayashi, M. Kikuchi, K. Yamazaki, S. Yamade, T. Ishida, K. Tatamidani, K. Hayashi, K. Sato, K. Hata, H. Kitaguchi, H. Kumakura, K. Osamura and J. Simoyama: "DI-BSCCO wire with $I_{\mathrm{c}}$ over $200 \mathrm{~A}$ at $77 \mathrm{~K}$, accepted in IEEE Trans. Appl. Supercond. (2009)

5) E. Hellstrom, D. Abraimov, A. Gurevich, F. Hunte, J. Jaroszynski, J. Jiang, F. Kametani, S. Kim, D. Larbakestier, A. Polyanskii, D. Rodrigues, B. Senkowicz, C. Tarantini, O. Uwakeh and A.Yamamoto: "Development of high-temperature superconductors for practical applications", Abstracts of CSJ Conference 78 (2008) 183

6) T. Matsushita, G. Isobe, K. Kimura, M. Kiuchi, S. Okayasu and W. Prusseit: "The effect of heavy ion irradiation on the critical current density in DyBCO coated conductors", Supercond. Sci. Technol. 21 (2008) 054014

7) J.S. Higgins and D.P. Hampshire: "Critical current measurements on HTS coated conductors in the picovolt regime - approaching the fundamental Johnson noise limit", submitted to Supercond. Sci. Technol. (2009)

8) K. Osamura, K. Itoh and T. Kuroda: "Standard test method of critical current for HTS composite tapes”, TML Annual Report, NIMS (2008)

長村光造, 伊藤喜久男, 黒田恒生 :「高温超電導線材の臨 界電流測定方法の標準化」, 物質 - 材料研究機構 強磁場共 用ステーション 年次報告書（2008）

9) B. ten Haken, A. Gedeke and H.H.J. Kate: "The influence of compressive and tensile axial strain on the critical properties of $\mathrm{Nb}_{3} \mathrm{Sn}$ conductors", IEEE Trans. Appl. Supercond. 5 (1995) 1909-1912

10) D.C. van der Laan and J.W. Ekin: "Dependence of the critical current of $\mathrm{YBa}_{2} \mathrm{Cu}_{3} \mathrm{O}_{7-\delta}$ coated conductors on in-plane bending", Supercond. Sci. Technol. 21 (2008) 115002 (6pp)

11) A. Nyilas and K.P.Weiss, "Bi-axial strain response of structural materials and superconducting $\mathrm{Nb}_{3} \mathrm{Sn}$ wires at $295 \mathrm{~K}, 7 \mathrm{~K}$ and 4 K", to be published in Adv. Cryog. Eng. (Materials) 2009.

12) K Osamura, S Machiya, H Suzuki, S Ochiai, H Adachi, N
Ayai, K Hayashi and K Sato: "Mechanical property and strain dependence of critical current of DI-BSCCO tapes," Supercond. Sci. Technol. 21（2008）054010（9pp）

13) M. Hojo, M. Hashimoto, M. Tanaka, T. Adachi, M. Sugano, S. Ochiai and K. Osamura: "Direct measurement of mechanical properties of Bi2223 filament using Ag alloy removed tape", Physica C 463-465 (2007) 863-866

14) S. Ochiai, T. Matsuoka, J.K. Shin, H. Okuda, M. Sugano, M. Hojo and K. Osamura: "Modeling analysis of the critical current of bent Bi2223 composite tape based on the damage strain parameter and the shape of the core", Supercond. Sci. Technol. 20 (2007) 1076-1083

15) K. Osamura, M. Sugano and K. Matsumoto: "Mechanical property and its influence on the critical current of Ag/Bi2223 tspes", Supercond. Sci Technol. 16 (2003) 971-975

16) M. Sugano, K. Osamura, W. Prusseit, R. Semerad, K. Itoh and T. Kiyoshi: "Intrinsic strain effect on critical current and its reversibility for YBCO coated conductors with different buffer layers", Supercond. Sci. Technol. 18 (2005) 369-372

17) K. Osamura, M. Sugano, S. Machiya, H. Adachi, S. Ochiai and M. Sato: "Internal residual strain and critical current maximum of YBCO coated conductor", Supercond. Sci. Technol. 22 (2009) 065001 (6pp)

18) M. Sugano, S. Machiya, K. Osamura, H. Adachi, M. Sato, R. Semerad and W. Prusseit: "The direct evalution of the internal strain of biaxially textured YBCO film in a coated conductor using synchrotron radiation", Supercond. Sci. Technol. 22 (2009) $015002(7 p p)$

19) K Osamura, S Machiya, H Suzuki, S Ochiai, H Adachi, N Ayai, K Hayashi and K Sato: "Improvement of reversible strain limit for critical current of DI-BSCCO due to lamination technique", accepted in IEEE Trans. Appl. Supercond. (2009)

20) Y. Miyoshi, M.C. Jewell and A. Nijhuis: "Systematic study on filament fracture distribution in ITER $\mathrm{Nb}_{3} \mathrm{Sn}$ strands", accepted in IEEE Trans. Appl. Supercond. (2009)

21) D.M.J. Taylor and D.P. Hampshire: "Properties of helical springs used to measure the axial strain dependence of the critical current density in superconducting wires", Supercond. Sci. Tech. 18 (2005) 356-368; N. Cheggour and D.P. Hampshire: "A probe for investigating the effects of temperature, strain, and magnetic field on transport critical currents in superconducting wires and tapes”, Rev. Sci. Instr. 71 (2000) 4521-4530

22) M. Sugano, T. Nakamura, T. Manabe, K. Shikimachi, N. Hirano and S. Nagaya: "The intrinsic strain effect on critical current under a magnetic field parallel to the c axis for a MOCVDYBCO-coated conductor", Supercond. Sci. Technol. 21 (2008) 115019 (8pp)

23) T. Kuroda, K. Itoh, K. Katagiri, W. Goldacker, W. Haessler, B. ten Haken, M. Kiuchi, K. Noto, S. Ochiai, S. Otabe, H.S. Shin, J. Sosnowski, H. Weijers, H. Wada and H. Kumakura: "Bending strain effect on critical current of Bi-2223 superconductor tapesreport of international round-robin-test", Physica C 425 (2005) 111-120

24) T. Kuroda, K. Katagiri, K. Itoh, H. S. Shin, H. Wada and H. Kumakura: "Tset methods of bending strain effects on critical 
current of Ag alloy-sheathed Bi-2223 superconductor tapes", J. Japan Inst. Metals 72 (2008) 268-277 (in Japanese)

25) S. Ochiai, J. K. Shin, H. Okuda, M. Sugano, M. Hojo, K. Osamura, T. Kuroda, K. Itoh and H. Wada: "Analysis of the distribution of critical current of bent Bi2223 composite tape based on a unifying parameter approach", Supercond. Sci. Technol. 21 (2008) 054002 (14pp)

26) A. Otto, E.J. Harley and R. Marson: "Critical current pretension in axially strained reinforced first-generation high-temperature superconducting Bi2223 wire", Supercond. Sci. Technol. 18 (2005) S308-S312

27) S. Ochiai, H. Rokkaku, K. Morishita, J. K. Shin, S. Iwamoto, H. Okuda, M. Hojo, K. Osamura, M. Sato, A. Otto, J. Harley and A. Malozemoff: "Thermally induced residual strain accumulation in Bi2223/Ag/Ag alloy composite superconductor", Supercond. Sci. Technol. 20 (2007) 202-210

28） S. Ochiai, H. Rokkaku, J. K. Shin, S. Iwamoto, H. Okuda, K. Osamura, M. Sato, A. Otto and A. Malozemoff: "Thermally and mechanically induced residual strain and strain tolerance of critical current in stainless steel-laminated Bi2223/Ag/Ag alloy composite superconductor", Supercond. Sci. Technol. 21 (2008) 075009 (13pp)

29) K. Osamura, M. Sugano, S. Machiya, H. Adachi, M. Sato, S. Ochiai and A. Otto: "Reversibility of micro-yielding and critical current in a YBCO-coated conductor caused by a uniaxial tensile load", Supercond. Sci. Technol. 20 (2007) S211-S216

30) K. Osamura, M. Sugano, K. Nakao, Y. Shiohara, A. Ibi, Y. Yamada, N. Nakajima, S. Nagaya, T. Saitho, Y. Ijima, Y. Aoki, T. Hasegawa and T. Kato: "Reversible strain limit of critical currents and universality of intrinsic elastic strain effect for REBCO coated conductors" Supercond. Sci. Technol. 22 (2009) 025015（7pp）

長 村 光 造 1970 年京都大学大学院工学研究科博士課 程冶金学専攻修了。同年より同大学工学部助手，同助教授を 経て，1985 年より京都大学工学部教授，2006 年 3 月同大学名 誉教授, 退職, 2006 年 4 月より（財）応用科学研究所 理事 · 主要研究員として現在に至る。この間主として超電導材料の組 織制御とその機能性の最適化に関する研究を行ってきた。日本 金属学会, 応用物理学会, 低温工学協会, 日本軽金属学会に所 属。京大工博。

和田仁 1974 年東京大学大学院冶金博士課程修了。 同年科技庁金属材料技術研究所電気磁気材料研究部研究員。核 融合炉用超伝導材料開発等に従事。2002 年物質・材料研究機 構磁場研究センター長。2004 年東京大学大学院新領域創成科 学研究科物質系専攻教授。低温工学協会, 日本金属学会, 日本 MRS, MRS, 米国セラミックス学会, 固体 NMR・材料フォー ラム, 磁気科学会会員。工学博士。

落 合 庄治郎 1976 年京都大学工学部冶金学科, 同大学 大学院冶金修士課程を経て同博士課程学修了。1977 年京都大 学工学部助手, 1987 年同助教授, 1992 年同教授, 2002 年同大 学国際融合創造センター教授, 2007 年同大学工学研究科教授,
現在に至る。超伝導複合線材・テープの力学挙動と超伝導特性 の相関，構造・機能複合材料の組織と物性に関する研究に従事。 日本金属学会, 日本材料学会, 低温工学協会等会員。京大工学 博士。

北 條 正 樹 1981 年京都大学大学院工学研究科修士課 程物理工学専攻修了。同年工業技術院製品科学研究所（現産業 技術総合研究所）研究員。1992 年京都大学工学部附属メゾ材 料研究センター助教授。2001年同工学研究科機械工学専攻教授。 2005 年改組により同機械理工学専攻教授, 現在に至る。超伝 導材料を含む各種複合材料の破壊とその微視機構の研究に従 事。低温工学協会, 日本機械学会, 日本材料学会, 日本複合材 料学会会員。工学博士。

松下 照 男 1972 年九州大学院工学研究科電子工学専 攻修士課程修了。1973 年九州大学工学部助手, 昭和 55 年同助 教授, 平成 2 年九州工業大学情報工学部電子情報工学科教授。 2006 年低温工学会長。2008 年九州工業大学大学院情報工学研 究院電子情報工学研究系教授, 現在に至る。超伝導体における 磁束ピンニングと電磁現象に関する研究に従事。低温工学協会 会員, 応用物理学会会員, 日本物理学会会員, 英国物理学会会 員。工学博士。

秋 田 調 1979 年東京大学大学院電気工学専門課程 修士課程修了。同年, (財) 電力中央研究所入所。主として超 電導電力機器の研究開発に従事。現在, 企画グループマネー ジャー。博士 (工学)。昭和 63 年度電気学会論文賞受賞。平成 5 年度電気学会論文賞受賞。低温工学協会正員, IEEE Fellow, 電気学会上級会員。

菅 野 未知央 2003 年京都大学大学院工学研究科材料工 学専攻博士後期課程修了。同年より, 独立行政法人物質 - 材料 研究機構強磁場研究センター特別研究員。2005 年より, 京都 大学大学院工学研究科電子工学専攻助手。2007 年より同助教, 現在に至る。超伝導複合材料の応力／ひずみによる破壊と物性 の変化に関する研究に従事。低温工学協会, 日本金属学会, 電 気学会会員。工学博士。

町 屋 修太郎 2006 年名古屋大学大学院工学研究科機械 工学専攻博士後期課程修了。同年より, 独立行政法人日本原子 力研究開発機構量子ビーム応用研究部門博士研究員。2008 年 より, 独立行政法人物質・材料研究機構中性子散乱グループ研 究員。同年より大同工業大学機械工学科講師, 現在に至る。超 伝導複合材料の X 線や中性子を用いた応力・ひずみ評価に関 する研究に従事。低温工学協会, 日本材料学会, 日本中性子科 学会会員。工学博士。

David LARBALESTIER 1970 年ロンドン大学にて学位を得る。 1978 年多芯 $\mathrm{Nb}_{3} \mathrm{Sn}$ 超伝導線を用いた NMR 用マグネットの作製 に関する共同研究に従事した。1981 年〜2005 年米国ウイスコ ンシン大学では, $\mathrm{Nb}-\mathrm{Ti}, \mathrm{Nb}_{3} \mathrm{Sn}$ 超電導材開発に精力的に取り組 んだ。現在, 国立強磁場研究センター付属応用超伝導センター・ センター長を務めている。

Arman NYILAS１962～1968 年ベルリン工科大学で金属製 
錬学を学ぶ。1970 年工学博士。1969〜1974 年ベルリン工科大 学研究員。1974 1979 年マンハイムの HRB で HTGR 用燃料 の開発研究に従事。1979～2006 年カールスルーエ中央研究所 で低温材料試験，低温材料開発に従事。現在，工学コンサルタ ント。

Werner PRUSSEIT 1994 年ミュンヘン工科大学博士課程修 了。THEVA 社を率いて, 第 2 世代テープ線材製造装置の開発, 線材の製造を行っている。
Alex OTTO アメリカンスーパーコンダクターズ上級研究員 で，第 2 世代テープの製造と特性評価に従事。

Damian HAMPSHIRE 1986 年オックスフォード大学大学 院博士課程修了。現在, 英国ダラム大学物理学教室教授。 Supercond. Sci. and Technol. 誌の編集委員長。 $\mathrm{Nb}_{3} \mathrm{Sn}$ 線材, 高温 超電導材料の機械電磁気特性やグラニュラー超電導材料の開発 等の研究に取り組んでいる。 